\title{
Utilization of fermented corn cob flour with "MOIYL" probiotics on local rabbit performance
}

\author{
I Arswandi, Yunilas, S Umar, A H Daulay, M Tafsin \\ Animal Production Program Study, Faculty of Agriculture, University of North \\ Sumatera, \\ Medan 20155, Indonesia \\ E-mail: Yunilas11@yahoo.co.id
}

\begin{abstract}
The study aims to evaluated thedetermine the effect of gave fermented corn cob by probiotic MOIYL to performance of local rabbit. Research conducted at Desa Bandar Klippa Deli Serdang and Agriculture Faculty of North Sumatera University, in January - March 2018. The study used design experiment by completely randomized design (CDR), which consists of 4 treatments and five replications. The treatment consisted of ration $\mathrm{P} 0=$ unfermented, $\mathrm{P} 1$ (10\% corn cob fermented and $20 \%$ unfermented), P2 (20\% corn cob fermented and 10\% unfermented), and P3 (30\% corn cob fermented). Variable measured were feed consumption, daily body weight gain, feed conversion ratio and income over feed cost.The results showed that fermented of corn cob with probiotics MOIYL provide a significant effect $(\mathrm{P}<0,05)$ towards body weight gain, consumption and Income Over Feed Cost and does not have an effect (P> 0.05 ) on the value of conversion. The conclusion from the results of this study is the provision of fermented corn cobs using MOIYL can increase body weight gain, consumption and Income Over Feed Cost, and tend to reduce the value of feed conversion.
\end{abstract}

\section{Introduction}

Rabbits are cattle that are expected to be able to help meet national meat needs. The potential for developing rabbits as meat-producing livestock is still very good, especially in North Sumatra. Aside from the uncomplicated maintenance, the litter size of rabbit is also quite high, reaching 7-9 heads per birth, Masanto and Agus [5].

The factors that influence rabbit meat production are one of them is the feed factor. Feed is the main factor that can determine the success of a farm. Inadequate availability of animal feed becomes a continuity problem, so it needs to be addressed with various innovations optimally. The nutritional quality of feed in rabbits also needs attention. Good feed quality is usually available in commercial rations. However, commercial rations on the market tend to have high prices and are not in accordance with the nutritional needs of rabbits so that alternatives are needed to find feed that is available continuously, cheap, easily available, has adequate nutritional value, and does not interfere with the health of livestock.

In 2015 corn plants had an area of 243,772 hectares with corn production of 1,519,407 tons with an average production of $62.33 \mathrm{kw} / \mathrm{ha}$ BPS North Sumatra [2]. According to Perry et al. [6] The components of old and ready-to-harvest corn plants consisted of 38\% seeds, $7 \%$ cob, $12 \%$ skin, $13 \%$ leaves and 30\% stems. Corn cobs are part of the corn fruit that has been extracted. Corn cobs can be given to livestock as a substitute for forage. If calculated in 2015, North Sumatra Province produces 106,359 tons of corn cobs that can pollute the environment. Therefore, corn cobs waste can be a potential alternative feed source. 
Corn cob or janggel, is part of the corn fruit after the seeds are piped. The nutritional content of corn cobs based on the analysis included water content (29.54\%), dry matter $(70.45 \%)$, crude protein (2.67\%) and crude fiber (46.52\%) in 100\% dry ingredients (BK) Pramono[7]. Corncob is a low quality residual agricultural product. The crude fiber content is high, protein and digestibility is low. Therefore, the role of biotechnology is needed to improve the quality of corn cobs, one of which is by using fermentation using local microorganisms (MOIYL Probiotics).

Indigenius Local Microorganisms are microorganisms that are exploited from their own substrate which have optimal ability to degrade fiber Yunilas [15]. According to Dwi [4], corn cobs inoculated with 5\% fungi Trichoderma sp. can reduce organic matter and increase crude protein content. Yulistiani et al. [13] reported that corn cobs fermented using Aspergillus niger microbes produced a crude protein content of $4 \%$ while corn cobs fermented with Trichoderma virede produced $3.4 \%$ protein. The composition of corn cob protein that has been fermented using microbes in general has increased, from 3\% to 6.1\% Warisman [11]. Research Objectives To examine and determine the effect of using fermented corncob flour using probiotics MOIYL on local rabbit performance.

\section{Materials and Research Methods}

\subsection{Time and Place of Research}

This research was conducted in Bandar Klifah Village, Deli Serdang Regency, North Sumatra Province. Laboratory of Nutrition Science and Animal Feed Animal Husbandry Study Program, Faculty of Agriculture, University of North Sumatra and Laboratory of Goat Cut Research Station, SeiPutihGalang. This research lasts for 8 weeks starting from January 2018 - March 2018.

\subsection{Materials and Research Tools}

The materials used are 20 male local rabbits with an average initial body weight of 404.4 grams \pm 9.14. Pellet treatment consists of fine bran, corn, soybean meal, coconut cake, fermented corn cobs, molasses, mineral mix, MOIYL Probiotics consisting of Bacillus sp YLB1, Trichodermasp YLF8 and Saccharomyces sp YLY3, drinking water, medicines and vitamins such as wormectin , B-complex, antibloat, rodalon as cage disinfectants.

The tools used are a 20 -unit enclosure with a size of $50 \times 50 \times 50 \mathrm{~cm}$, a pellet printer, a body weight scale with a capacity of $15 \mathrm{~kg}$ with a sensitivity of $10 \mathrm{~g}$, an electric scale with a capacity of $3 \mathrm{~kg}$ with a sensitivity of $1 \mathrm{~g}$, a place to feed and drink in each cage with a total of 20 units, cage cleaning tools, cage lighting tools, chopper machines for chopping corn cobs, grinders to smooth feed ingredients and stationery to write data.

\subsection{Research Method}

The research method used was experimental using a completely randomized design (CRD) consisting of 4 treatments and 5 replications. The treatments given are as follows:

P0: Ration without fermented corn cobs

P1: $10 \%$ fermented corn cobs

P2: $20 \%$ fermented corn cobs

P3: $30 \%$ fermented corn cobs

Composition of research treatments (randomization of treatments and replications)

\begin{tabular}{lllll}
\hline $\mathrm{P}_{2} \mathrm{U}_{3}$ & $\mathrm{P}_{0} \mathrm{U}_{2}$ & $\mathrm{P}_{1} \mathrm{U}_{4}$ & $\mathrm{P}_{3} \mathrm{U}_{2}$ & $\mathrm{P}_{2} \mathrm{U}_{2}$ \\
$\mathrm{P}_{3} \mathrm{U}_{4}$ & $\mathrm{P}_{1} \mathrm{U}_{3}$ & $\mathrm{P}_{0} \mathrm{U}_{3}$ & $\mathrm{P}_{2} \mathrm{U}_{1}$ & $\mathrm{P}_{1} \mathrm{U}_{1}$ \\
$\mathrm{P}_{0} \mathrm{U}_{1}$ & $\mathrm{P}_{2} \mathrm{U}_{4}$ & $\mathrm{P}_{2} \mathrm{U}_{5}$ & $\mathrm{P}_{1} \mathrm{U}_{5}$ & $\mathrm{P}_{3} \mathrm{U}_{3}$ \\
$\mathrm{P}_{1} \mathrm{U}_{2}$ & $\mathrm{P}_{3} \mathrm{U}_{5}$ & $\mathrm{P}_{3} \mathrm{U}_{1}$ & $\mathrm{P}_{0} \mathrm{U}_{4}$ & $\mathrm{P}_{0} \mathrm{U}_{5}$ \\
\hline
\end{tabular}

\subsection{Parameters Observed}

Ration Consumption

Ration consumption was calculated by weighing the amount of feed given minus the remaining feed during the study expressed in $\mathrm{g} / \mathrm{head} /$ day in the form of dry matter (BK) Consumption $=$ Feed given - leftover feed ( $\mathrm{g} / \mathrm{head} /$ day). 
Weight Gain (WG)

Daily weight gain was the difference between initial body weight and final body weight divided by the length of maintenance expressed in $\mathrm{g} / \mathrm{head} /$ week

$$
\mathrm{WG}=\underline{\text { final weight }}=\underline{\text { initial weight }}
$$

Ration conversion

Feed conversion is a comparison between the amount of feed consumption with daily body weight gain during maintenance.

$$
\text { Feed conversion }=\frac{\text { Feed consumption }(\mathrm{g} / \mathrm{day})}{\mathrm{WG}}
$$

Income Over Feed Cost (IOFC)

Income Over Feed Cost (IOFC) is the difference between business income and feed costs. Revenue is a multiplication between production and selling prices, while feed costs are costs incurred to produce the weight of live rabbits.

Income Over Feed Cost $(\mathrm{IOFC})=$ rabbit price $\mathrm{x}($ final weight - initial weight $)-$ feed cost

\subsection{Data analysis}

The data obtained were analyzed using analysis of variance (ANOVA) if between treatments there was a real effect then it would be continued by using Duncan's Distance Distinction Test.

\subsection{Implementation of Research}

Preparation of cages and equipment, preparation of rabbits, randomization of rabbits, processing of corn cobs, feeding and drinking, administration of medicines and data collection.

\section{Results and Discussion}

\subsection{Consumption ( $g$ / head / day)}

Feed consumption can be calculated by reducing the amount of feed given with the remaining feed available. Data on consumption of dry ingredients of local rabbit feed during the study can be seen in Table 1 below:

Table 1. Average consumption of dry ingredients of male local rabbit feed during the study (g/head / day).

\begin{tabular}{ccccccc}
\hline Treatment & \multicolumn{5}{c}{ Repeat } & Average \pm Sd \\
\hline & U1 & U2 & U3 & U4 & U5 & \\
\hline P0 & 65.371 & 66.543 & 66.243 & 66.314 & 65.229 & $65.94 \pm 0.5^{\mathrm{A}}$ \\
P1 & 64.600 & 69.314 & 69.714 & 66.957 & 69.129 & $67.94 \pm 2.1^{\mathrm{AB}}$ \\
P2 & 69.657 & 69.557 & 71.086 & 66.529 & 69.343 & $69.23 \pm 1.6^{\mathrm{B}}$ \\
P3 & 71.257 & 69.657 & 71.914 & 69.671 & 70.900 & $70.68 \pm 0.9^{\mathrm{C}}$ \\
\hline
\end{tabular}

Description: superscripts with different uppercase letters toward the column show a very significant effect (P $<0.01)$.

Duncan's further test results showed that P3 treatment feed consumption was significantly higher than that of P2 treatment, P2 was significantly higher than treatment P1 and lower than P3 and P1 was significantly higher than treatment P0 and lower than treatment P2. The presence of significant differences in dry matter consumption is thought to be due to the fermentation process in treatment feed P3, P2, and P1 which causes higher dry matter consumption compared to treatment P0 (ration without fermented corn cobs). The higher the level of fermented corn cobs, the more ration consumption. This is due to the palatability of the ration fermented with probiotics MOIYL, the aroma of feed that is preferred by livestock, physical conditions of livestock during maintenance and 
environmental conditions that can affect consumption of livestock. This is in accordance with the statement of Simanjuntak et al [9] which states that the high level of ration consumption is due to the superior physical properties of the ration, which is better, more fragrant and has higher nutritional value because fermentation can add flavor and aroma.

From the results of the study, it can be seen that the higher the level of fermented corncob giving, the more ration consumption. This is because the ration using probiotics MOIYL has a sour aroma quality that is preferred by rabbits. The fermentation process also causes nutrients such as crude protein to increase and crude fiber to decrease so that the digestion process in fermented rations occurs faster. This is because in probiotics MOIYL contains bacteria, fungi and yeast in the form of Bacillus sp YLB1, Trichoderma sp YLF8 and Saccharomyces sp YLY3 including microbes that have high ability to degrade fiber (lignocellulose) Yunilas et al., [14] and Yunilas, [15].

\subsection{Weight gain (g/head / day)}

Weight gain was calculated every week based on the difference between weighing the final body weight and weighing the initial body weight. From the results of the research that has been done, the average body weight of male rabbits is obtained during the study as shown in Table 2 below.

Table 2. Average treatment of weight gain

\begin{tabular}{ccccccc}
\hline Treatment & \multicolumn{5}{c}{ Repeat } & Average \pm Sd \\
\hline & $\mathrm{U} 1$ & $\mathrm{U} 2$ & $\mathrm{U} 3$ & $\mathrm{U} 4$ & $\mathrm{U} 5$ & \\
\hline P0 & 10.557 & 10.782 & 9.018 & 12.114 & 10.395 & $10.57 \pm 1.1^{\mathrm{A}}$ \\
P1 & 11.070 & 9.711 & 11.538 & 12.879 & 11.682 & $11.37 \pm 1.14^{\mathrm{AB}}$ \\
P2 & 12.609 & 12.465 & 12.600 & 13.671 & 12.600 & $12.78 \pm 0.49^{\text {BL }}$ \\
P3 & 11.340 & 13.392 & 14.697 & 15.795 & 12.681 & $13.58 \pm 1.73^{\mathrm{C}}$ \\
\hline
\end{tabular}

Description: superscripts with different uppercase letters toward the column show a very significant effect (P $<0.01)$

Duncan's further test results showed that the body weight gain in treatment P3 was significantly higher than that of treatment P2, P2 was significantly higher than treatment P1 and lower than P3 and $\mathrm{P} 1$ was significantly higher than treatment $\mathrm{P} 0$ and lower than treatment $\mathrm{P} 2$. There were significant differences the increase in body weight was also due to the fermentation process in treatment feed P3, $\mathrm{P} 2$, and P1 which caused higher nutrient content in the form of protein and crude fiber lower than the treatment P0 (fermented corn cobs without fermented corn). manifest to the increase in body weight of male local rabbits. This shows that the provision of fermented corn cobs using probiotics MOIYL can increase the body weight of rabbits.

The results showed that rations with fermented corn cobs were preferred by livestock so their consumption increased compared to fermented corncob rations. This resulted in increased body weight of livestock. This is closely related to consumption, where consumption is directly proportional to body weight gain. This is in accordance with Yudiar's opinion which states that the body weight of livestock is always directly proportional to the level of feed consumption, the higher the body weight the higher the feed consumption. In addition, from the analysis of corn cobs fermented with probiotics MOIYL can increase the nutritional content of corn cobs, such as increasing its protein content which affects the growth of the rabbit's livestock and reduce the crude fiber content of the corn cobs. This is in accordance with Yunilas et al's [14] statement which stated that the difference in daily body weight gain was also due to the fermentation of industrial waste with indigenous microbes which could increase protein content and reduce crude fiber. According to Rasyid [8], one factor that affects body weight is feed consumption and feed digestibility. Feed consumption and high feed digestibility will produce high body weight, this is caused by the more nutrients absorbed by the animal's body.

\subsection{Ration Conversion}

The ration conversion in this study was calculated in the form of dry matter by comparing the amount of feed consumed with the body weight gain achieved every week. The average conversion rate during the study can be seen in Table 3 . 
Table 3. Average conversion of male local rabbit rations during the study

\begin{tabular}{ccccccc}
\hline Treatment & \multicolumn{7}{c}{ Repeat } & Average \pm Sd \\
\hline & $\mathrm{U} 1$ & $\mathrm{U} 2$ & $\mathrm{U} 3$ & $\mathrm{U} 4$ & $\mathrm{U} 5$ & \\
\hline P0 & 6.15 & 6.15 & 7.60 & 5.54 & 6.39 & $6.37 \pm 0.75^{\text {tn }}$ \\
P1 & 5.87 & 7.44 & 6.06 & 5.19 & 5.87 & $6.09 \pm 0.82^{\text {tn }}$ \\
P2 & 5.51 & 5.61 & 5.65 & 4.91 & 5.58 & $5.45 \pm 0.30^{\text {tn }}$ \\
P3 & 6.29 & 5.18 & 4.88 & 4.43 & 5.59 & $5.28 \pm 0.70^{\text {tn }}$ \\
\hline
\end{tabular}

Description: Superscript with letters ${ }^{\mathrm{tn}}$, shows an insignificant influence.

The table above can be seen that the lowest average conversion of male local rabbit rations is P3 5.28 \pm 0.70 and the highest is $\mathrm{P} 0$ of $6.37 \pm 0.75$. The results of diversity analysis showed that giving various levels of fermented corncob on local rabbits' animal feed had no effect $(\mathrm{P}>0.05)$ on the conversion of male local rabbit rations.

The provision of fermented corn cobs did not affect the conversion of male local rabbit rations but tended to decrease in the treatment using probiotic MOIYL, which can be seen from the United Nations. In the fermented treatment using probiotics MOIYL was greater than the treatment without fermentation. This shows that the provision of fermented corn cobs using probiotics MOIYL can provide ration efficacy in rabbits.

From the results of the study it can be seen that the ration conversion value in rabbits is not different but tends to decrease. This is caused by rations using probiotics MOIYL having better palatability but the amount of feed consumed. According to Amalia [1], feed conversion is influenced by several factors, including; genetic factors, ration quality (conversion of rations that are getting smaller or more efficient will show good quality rations), sex of livestock, good cages, and good air ventilation.

\subsection{Income Over Feed Cost (Rp)}

Income Over Feed Cost (IOFC) is the difference between livestock business income and feed costs. Revenue is a multiplication between livestock production (in kilograms of life) and selling price. While the cost of feed is the cost incurred to produce the kilogram of live rabbits. Income Over Feed Cost rabbits during the research can be seen in Table 4 below:

Table 4. Income over feed cost (IOFC)

\begin{tabular}{ccccccc}
\hline Treatment & \multicolumn{5}{c}{ Repeat } & Average \pm Sd \\
\hline & $\mathrm{U} 1$ & $\mathrm{U} 2$ & $\mathrm{U} 3$ & $\mathrm{U} 4$ & $\mathrm{U} 5$ & \\
\hline $\mathrm{P} 0$ & 48114.4 & 49224.8 & 38149.2 & 57659.1 & 47164.6 & $48062.4 \pm 6937.7^{\mathrm{A}}$ \\
P1 & 51209.8 & 41306.8 & 52712.0 & 61963.3 & 53690.1 & $52176.4 \pm 7372.9^{\mathrm{AB}}$ \\
P2 & 59088.3 & 58217.5 & 58617.9 & 66663.7 & 58550.2 & $60227.5 \pm 3611.3^{\mathrm{BC}}$ \\
P3 & 50301.1 & 63558.2 & 71165.1 & 78763.9 & 58777.6 & $64513.2 \pm 10990^{\mathrm{C}}$ \\
\hline
\end{tabular}

Description: Superscripts with different uppercase letters toward the column show a significant effect $(\mathrm{P}$ $<0.05)$.

The table above can be seen that the lowest Income Over Feed Cost of male local rabbit rations is P0 of Rp. $48062.4 \pm 6937.7$ and the highest Income Over Feed Cost ration is P3 of Rp. $64513.2 \pm 1099$. The results of diversity analysis showed that giving various levels of fermented corncob flour to local rabbits' animal feed had a significant effect $(\mathrm{P}>0.05)$ on Income Over Feed Cost of local male rabbit rations.

Income Over Feed Cost is the difference between income and feed costs (Suparman, 2004). In table 7, it can be seen that the average Income Over Feed Cost results of the research for treatments P0, P1, P2, and P3 are Rp 48062.4; Rp. 52176.4; Rp. 60227.5; and Rp64513.2. The results showed that the lowest Income Over Feed Cost was achieved by P0 (control) while the highest was achieved by P3. This means that the ration in the control treatment consumes the highest feed costs, while the higher use of probiotic MOIYL in rations causes the cost of feed needed to be lower (cheaper). This is 
because to increase the body weight of $1 \mathrm{~kg}$ only in cattle with treated feed requires more feed so that the cost of feed becomes higher. This means that in terms of feed costs, rations using probiotic MOIYL components are more efficient to use as feed for rabbits. This is due to Income Over Feed Cost from the treatment feed influenced by the conversion and cost of the treated feed, in this case P3 has the lowest feed conversion rate when compared to $\mathrm{P} 0$.

In accordance with the opinion of Christiana [3], that the lower the Income Over Feed Cost, the lower the cost to be incurred for weight gain in the same unit, which means more economical or otherwise. to arrange rations must be as cheap as possible and be available continuously or can also use noncompetitive agricultural waste.

\section{Conclusion}

From the results of the study it can be concluded that giving fermented corn cobs up to $30 \%$ can increase body weight gain, consumption and Income Over Feed Cost, mathematically the conversion value in each treatment tends to decrease and fermented corn cobs with probiotics MOIYL are both given as alternative feeds for local rabbit.

\section{References:}

[1] Amalia, A. 2008. Pembuatan Stater/ MOL (Mikroorganisme Lokal) oleh Petani. Diakses dari : http://organicfield.wordpress.com/.

[2] Badan Pusat Statistik Provinsi Sumatera Utara. 2015. Limbah Tongkol jagung dalam Angka 2015.

[3] Christiana, N. 2012. Efisiensi dan Kecernaan Serat Ransum Mangandung Limbah Tauge Pada KelinciLokal Jantan Masa Pertumbuhan. Diakses dari https://repository.ipb.ac.id/bitstream/handle/123456789/6141/D12nch.pdf [22 November 2018]

[4] Dwi, Y, A. 2015. Kandungan Bahan Organik dan Protein Kasar Tongkol Jagung (Zea mays) yang Diinokulasi dengan Fungi Trichoderma sp Pada Lama Inkubasi yang Berbeda. Diakses Dari http://repository.unhas.ac.id/bitstream/handle/123456789/14385/YATTI\%20DWI\%20ARIY NTI\%20S.pdf; sequence $=1$ [20 November]

[5] Masanto dan Agus. 2010. Pengantar Teknik Penelitian : Degradasi Pakan Ternak Ruminansia. Brilian Internasional, Surabaya.

[6] Perry TW, Cullison AE, Lowrey RS. 2003. Feeds And Feeding. $6^{\text {th }}$ Ed. New Jersey: Prentice Hall inc

[7] Pramono, E. 2016. Daya Cerna Bahan Kering Dan BahanOrganik Pelet Pakan KomplitBerbasis Tongkol Jagung Dengan Sumber Protein Berbeda pada Kambing. Diakses dari: http://repository.unhas.ac.id/bitstream/handle/123456789/17143/EKO\%20PRAM O\%20\%28I11111276\%29.pdf? sequence $=1$ [27 November 2018].

[8] Rasyid, H. 2009. Performa Produksi Kelinci Lokal Jantan Pada pemberian Rumput Lapang dan Berbagai Level Ampas Tahu. Institut Pertanian Bogor.

[9] Simanjuntak, S., Yunilas., M. Tafsin. 2015. Fermentasi Industri Hasil Samping Dan Perkebunan Kelapa Sawit Dengan Probiotik Lokal Terhadap Performans Domba. Jurnal Peternakan Integratif Vol. 4 No.1 Desember 2015 : 83-95

[10] Suparman, D., 2004. Kinerja Produksi Kelinci Lokal Jantan dengan Pemberian Pakan Kering vs Basah. Universitas Gadjah Mada Press. Yogyakarta..

[11] Warisman. 2014. Pengolahan Secara Biologis Dalam Meningkatkan Kualitas Nutrisi Tongkol Jagung Fermentasi Sebagai Pakan Domba. Tesis. Program Studi Peternakan Fakultas Pertanian Universitas Sumatera Utara. Medan 
[12] Yudiar, R. R., M. Tafsin., N. D. Hanafi. 2014. Pemanfaatan Tongkol Jagung Dengan Starbio, Aspergillus Niger, Dan Trichoderma Viride TerhadapKecernaan Protein Kasar Dan Serat Kasar Pada Domba Jantan Lokal Lepas Sapih. J.Peternakan Integratif Vol.2 No.3; 311-320.

[13] Yulistiani, D. 2012. Silase Tongkol Jagung untuk Pakan Ternak Ruminansia. Tabloid Sinartani Badan Litbang Pertanian. Edisi 18-24 juli 2012 No. 3466

[14] Yunilas, Lili Warly, Yetti Marlida., and Irsan Ryanto. 2013. Protency of Indeginous Bakteria From Oil Palm Waste in Degrades Lignocellulose as a Sources of Inoculum Fermented to High Fibre feed. Pakistan Journal of Nutrition 12(9) : 851-853.

[15] Yunilas. 2016. Peran Mikroorganisme Indigenous YL (MOIYL) Sebagai Inokulum Pendegradasi Serat Berbasis Limbah Perkebunan Sawit. Prosiding Seminar Nasional Peternakan Berkelanjutan 8, 16 November 2016. Sumedang. Indonesia. 